\title{
Comparative Evaluation of the Effect of Surface Polishing of a Glaze/composite Sealant and Different Polishing Systems on Surface Roughness of Three Composite Resin Type
}

\author{
MARIA BOLAT ${ }^{1}$, SIMONA STOLERIU ${ }^{1 *}$, GIANINA IOVAN ${ }^{1}$, GALINA PANCU ${ }^{1}$, NICOLETA TOFAN ${ }^{1}$, ANDREI VICTOR SANDU ${ }^{2,3}$, \\ SORIN ANDRIAN ${ }^{1}$ \\ ${ }^{1}$ Grigore T. Popa University of Medicine and Pharmacy of Iasi, Faculty of Dental Medicine,16 Universitatii Str., 700115 Iasi, \\ Romania \\ ${ }^{2}$ Gheorghe Asachi Technical University of lasi, Faculty of Material Science and Engineering, 61A D. Mangeron Blvd., 700050 lasi, \\ Romania \\ ${ }^{3}$ Romanian Inventors Forum, 3 Sf. Petru Movila, Str. BI. L11, Sc. III, Et. 3, Ap.3, 700089, Iasi, Romania
}

\begin{abstract}
The aim of the study was to evaluate the influence of different techniques of finishing and polishing as well as the use of sealants on the surface condition of some composite resins used in the dental office. 80 specimens of composite materials (Nanoceramic, Nanocomposit and Nanohybrid) were made and divided into 3 groups G1-coated composite with sealant lacquer, G2 - finished in 2 stages, and G3 - finished in 3 stages. Roughness ( $R a$ ) was determined with the Taylor Hobson Form Talysurf Profiometer. The data was analyzed using one-way ANOVA followed by a multiple comparison $t$ test. Significant differences were found between the groups in terms roughness $(p<0.001)$. The results showed that Seal - and - Shine (PULPDENT) was capable of reducing surface roughness and provided polished surfaces for all materials.
\end{abstract}

Keywords: composite; finishing; polishing; profilometer; surface roughness

Composite materials have become some of the most used in restorative dentistry due to their aesthetic characteristics and mechanical properties. Over time, composite resins have been classified according to different criteria, but the most important of these was the amount of filler. Analyzing their evolution over time, one can see how the macrofiller (classical composites with particles larger than $1 \mu \mathrm{m}$ ) has passed to the microfiller (particle size $0.002-0.04 \mu \mathrm{m})$ and hybrids $(0.6-1.0 \mu \mathrm{m})$ to microhybrid, and now the newest types of composite resins available on the market are nanofiller (20-75 $\mu \mathrm{m})$ and nanoceramic [1,2]. An important factor in the success of a composite restoration is surface finishing. Obtaining a smooth, glossy surface was considered a major goal, not only for aesthetic reasons, but also for oral health. Incomplete finishing of restored surfaces can result in dental plaque accumulation, gingival inflammation, periodontal problems, demineralisation of the dental structure, appearance of stains or caries adjacent to composite resin restorations [3-5]. Finishing of composite resins refers to coarse contours and rendering of desired anatomy, while polish refers to roughness reduction and removal of scratches created by finishing tools [6-8]. The final finishing of the composites depends on the particle size of the material, the filling load, the quality and, last but not least, the polishing material used.

Composite resins respond differently to polishing and finishing because they are manufactured from different components and do nothave the same hardness properties. The existence in the dental market of numerous techniques and technologies for finishing and polishing composite resins gives us the possibility to have the best choice for each type of composite used. Thus, silicone disks, cups with different types of abrasives, soap-lex impregnated brushes, abrasive tapes, rotary tools with diamond particles, polishing paste, etc. can be found. The use of finishing and polishing methods of a composite resin restoration made according to a special protocol may vary between 10 and
30 minutes, which is why glazing materials or surface sealants that seal composite restorations are increasingly being used, eliminating the final finishing and mechanical polishing steps and provides a natural shine to the restoration.

The qual ity of the surface of composite resin restorations is one of the most important factors determining clinical success in the oral cavity. The existence of a certain degree of roughness of the surface of composite resins is favored by the type, shape, dimensions and composition of the particles forming the inorganic phase, the quality and quantity of the organic component, the type of adhesive and the photopolymerization system $[9,10]$. Smooth surfaces reduce the risk of adhesion of bacterial biofilm, marginal side caries, gingival irritation and color changes [11, 12].

Roughness of restored surfaces influences the adherence of bacteria that can cause gingival, recurrent or periodontal disease in time. To avoid bacterial adhesion, various studies have found that roughness $(\mathrm{Ra})$ should have average values ranging from $0.7-1.44 \mu \mathrm{m}$ [13], $0.2 \mu \mathrm{m}$ [10]and $0.25-0.50 \mu \mathrm{m}$ [9].

The aim of the study was to evaluate the influence of different techniques of finishing and polishing as well as the use of sealants on the surface condition of three types of composite resins (Nanoceramic, Nanocomposit and Nanohybrid) used in the dental office.

\section{Experimental part}

Materials and methode

Materials used in this study were Tetric Evoceram (IVOCLAR), Filtek Ultimate Universal Restorative (3M ESPE), and Admira Fusion (VOCO), Composite Finishing Cutters (NTI), Composite Polishing Gum (NTI), Paste (ULTRADENT) and Embrace ${ }^{\text {TM }}$ WetBond $^{\text {TM }}$ Seal-n-Shine ${ }^{T M}$ (PUPLDENT) Embrace ${ }^{\text {TM }}$ sealant. The description of the materials is presented in table 1. 
Tabel 1

MATERIALS USED IN THE STUDY

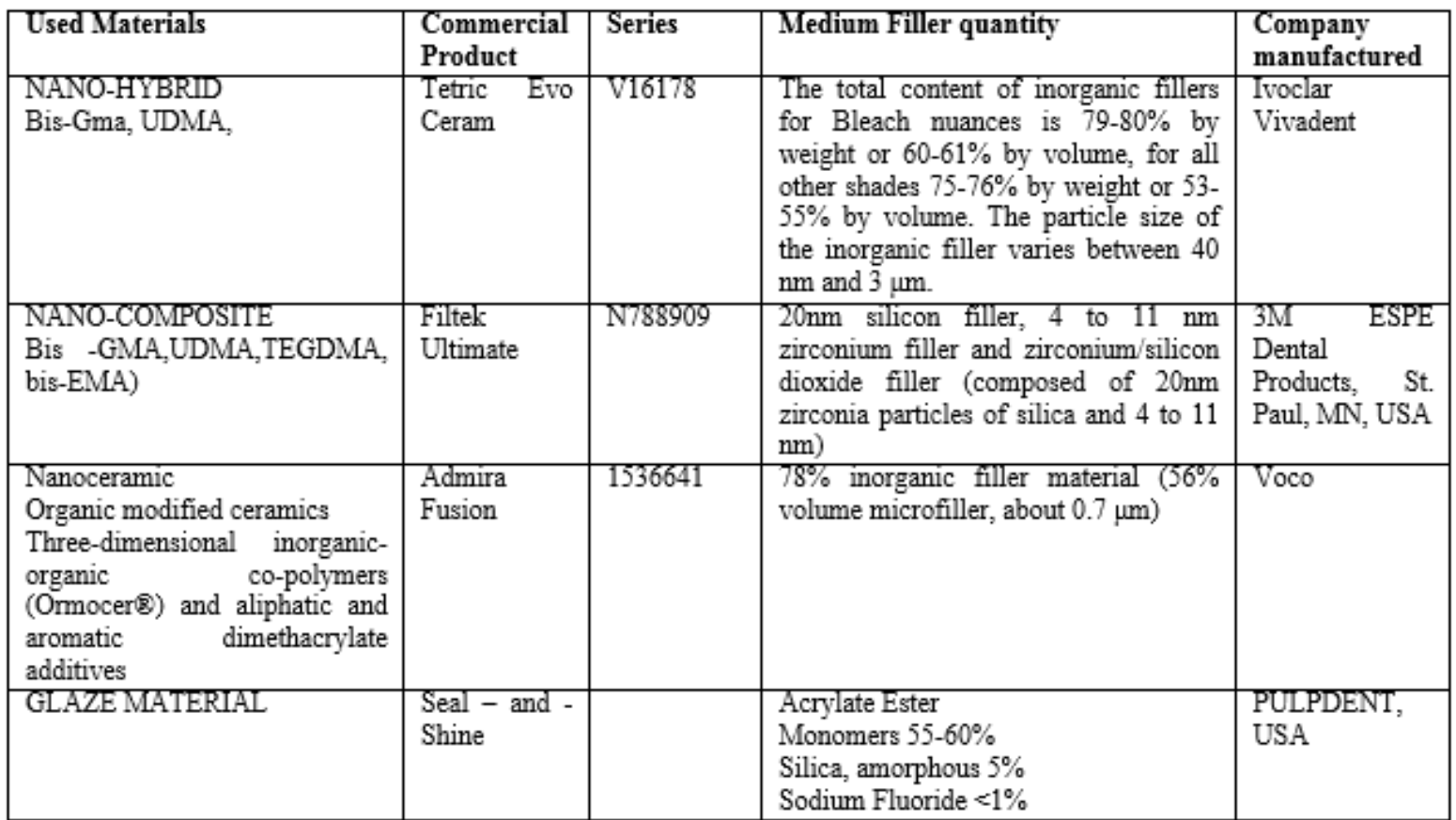

This 80 samples of composite material made in teflon molds $10 \mathrm{~mm}$ in diameter, photopolymerized on both sides by the glass plate and under a celluloid band to ensure complete material curing and to provide a uniform surface, without any irregularities or bumps. The polymerization was carried out using a Kerr Demi Plus LED (light emitting diode) LED with a wavelength of $450-470 \mathrm{~nm}$ - figure. The 80 composite discs were divided into three groups as follows:

$\mathrm{Gl}(\mathrm{n}=20)$ - for which, after the curing of the composite, it was covered with a sealant (Seal and Shine - Pulpdent, USA) by applying it with the help of a brush and subsequent curing of the cure as specified by the manufacturer;

$\mathrm{G} 2(\mathrm{n}=20)$ composites finished in two stages - 1 . Finishing with special composite burrs (NTi), 2. Sof-lex (3M ESPE);

$\mathrm{G} 3(\mathrm{n}=20)$ composites finished in three stages: 1 . Finishing with special composite burrs (NTi), 2. Sof-lex (3M ESPE) in combination with $1 \mu \mathrm{m}$ diamond particle paste (Ultradent) (NTI) and 0.5um paste (ULTRADENT)

Control.G $(n=20)$ polymerization under Mylar band to avoid bumps.

All finishing and polishing procedures, as well as sealing procedures, were performed by a single practitioner in accordance with the manufacturer's instructions. Thus, finishing with special frets was done at conventional speeds that do not exceed 10,000 revolutions, under continuous irrigation with water. Sof-lex (3M) spiral discs were used at 4,000 rpm for $15 \mathrm{~s}$, and the grains without granulation at $4500 \mathrm{rpm}$ for $20 \mathrm{~s}$. Specimens from each group were then maintained after profilometry for 90 days in AFNOR artificial saliva. After 90 days, the profile tests were resumed.

The material roughness was determined using the Taylor Hobson Form Talysurf Intra profile. The Taylor-Hobson Form Talysurf Intra performs the analysis of surface microtropography, measurement and calculation of the usual parameters according to the standards: DIN EN ISO 4287; DIN 4288; DIN EN ISO 13565; ISO 12085; DB N 31007; J IS B 601; Measuring accuracy: $3 \mathrm{~nm}$ for a variation of $0.2 \mathrm{~mm}$ in height and maximum $16 \mathrm{~nm}$ at a variation of $1 \mathrm{~mm}$ in height; Measurement precision for form deviations:
Radius error: $0.04 \%$ - $2 \%$; angular measurement error: $1 \%$, with the limit of $+/-350$.

\section{Results and discussions}

The mean roughness values for each group ( $G 1, G 2$ and G3) were determined and presented in table 2. Roughness mean value for $\mathrm{G} 1$ was 0.521 after $24 \mathrm{~h}$ and 0.285 after 90 days, for $\mathrm{G} 2$ the results were 0.259 at $24 \mathrm{~h}$ and 0.253 after 90 days, and for $\mathrm{G} 3$ it was found after $24 \mathrm{~h}$ a value of 0.302 and respectively 0.279 after 90 days.

Table 2

STATISTICAL ROUGHNESS VALUES AFTER 24 HOURS AND 90 DAYS

\begin{tabular}{|l|l|l|l|}
\hline \multicolumn{4}{|c|}{ Descriptive Statistics } \\
\hline & N & Mean & Std. Deviation \\
\hline & Statistic & Statistic & Statistic \\
\hline G1 - 24H & 20 & $\mathbf{0 . 5 2 1}$ & 0.0463 \\
\hline G2 - 24H & 20 & $\mathbf{0 . 2 5 9}$ & 0.03 \\
\hline G3 - 24H & 20 & $\mathbf{0 . 3 0 2}$ & 0.0295 \\
\hline G1 - 90Z & 20 & $\mathbf{0 . 2 8 5}$ & 0.0335 \\
\hline G2 - 90Z & 20 & $\mathbf{0 . 2 5 3}$ & 0.0311 \\
\hline G3 - 90Z & 20 & $\mathbf{0 . 2 7 9}$ & 0.0221 \\
\hline $\begin{array}{l}\text { Valid } \\
\text { (listwise) }\end{array}$ & 20 & & \\
\hline
\end{tabular}

At $\mathrm{Gl}$, the roughness was significantly lower in the Nanoceramic group compared to Nanocomposite $(0.33$ vs. $0.35 ; p=0.015)$ and the Nanohibrid group ( 0.33 versus $0.36 ; p=0.005$ ) respectively. At $G 2$, the roughness was the same for the Nanoceramic and Nancomposite groups ( 0.36 vs. $0.36, p=0.284)$ and respectively significantly lower than the Nanohibrid group (0.36 vs. $0.40, p=0.001$ ). At $\mathrm{G} 3$, the roughness was significantly lower in the Nanoceramic group compared to Nanocomposite $(0.38$ versus $0.41 ; p=0.001$ ) and the Nanohibrid group (0.38 vs. $0.45 ; p=0.001$ ) respectively (table 3 ).

At G1, roughness did not show significant differences across study groups. At $\mathrm{G} 2$, the roughness was significantly lower in the Nanocomposite group compared to the Nanoceramic groups ( 0.28 vs. $0.30, p=0.007)$ and Nanohibrid ( 0.28 vs. $0.33, p=0.001$ ). At G3, the roughness was slightly lower in the Nanocomposite group compared to Nanoceramic ( 0.27 vs $0.29, p=0.119$ ) and significantly 
Table 3

THE CORRELATION OF THE ROUGHNESS WITH THE FINISHING AND SEALING SOLUTION AT THE TIME TO COMPARED TO STUDY LOTS

\begin{tabular}{|c|c|c|c|c|c|c|c|}
\hline \multicolumn{5}{|c|}{ Roughness } & Control G vs & Control G vs & Control G vs \\
\hline Nanoceramic & GI & G2 & G3 & Control G & $p=0.001$ & $p=0.001$ & $p=0.001$ \\
\hline Average & 0.33 & 0.36 & 0.38 & 0.59 & G1 vs G2 & G1 vs G3 & G2 vs G3 \\
\hline SD & 0.02 & 0.02 & 0.03 & 0.05 & $p=0.001$ & $p=0.001$ & $p=0.006$ \\
\hline Nanocompozit & $\mathrm{Gl}$ & $\overline{\mathrm{G} 2}$ & G3 & Control G & $p=0.001$ & $p=0.001$ & $p=0.001$ \\
\hline Average & 0.35 & 0.36 & 0.41 & 0.59 & G1 vs G2 & G1 vs G3 & $\mathrm{G} 2$ vs G3 \\
\hline SD & 0.02 & 0.02 & 0.03 & 0.05 & $p=0.046$ & $p=0.001$ & $\mathrm{p}=0.001$ \\
\hline Nanohibrid & $\overline{\mathrm{Gl}}$ & $\overline{\mathrm{G} 2}$ & $\overline{\mathrm{G} 3}$ & Control G & $p=0.001$ & $p=0.001$ & $p=0.001$ \\
\hline Average & 0.36 & 0.40 & 0.45 & 0.59 & G1 vs G2 & $\mathrm{G} 1$ vs $\mathrm{G} 3$ & $\mathrm{G} 2$ vs G3 \\
\hline SD & 0.02 & 0.05 & 0.05 & 0.05 & $p=0.001$ & $p=0.001$ & $\mathrm{p}=0.001$ \\
\hline
\end{tabular}

Table 4

THE CORRELATION OF THE ROUGHNESS WITH THE FINISHING AND SEALING SOLUTION AFTER 90 DAYS COMPARED TO STUDY LOTS

\begin{tabular}{|c|c|c|c|c|c|c|c|}
\hline \multicolumn{5}{|c|}{ Roughness } & \multirow{2}{*}{$\begin{array}{c}\text { Control G } \\
\text { vs } \mathrm{Gl} \\
\mathrm{p}=0.001\end{array}$} & \multirow{2}{*}{$\begin{array}{c}\text { Control G } \\
\text { ws } \mathrm{G} 2 \\
\mathrm{p}=0.001\end{array}$} & \multirow{2}{*}{$\begin{array}{c}\begin{array}{c}\text { Control G } \\
\text { vs G3 }\end{array} \\
p=0.001\end{array}$} \\
\hline Nanoceramic & GI & G2 & G3 & Control G & & & \\
\hline Medie & 0.26 & 0.30 & 0.29 & 0.52 & G1 vs G2 & G1 vs G3 & $\mathrm{G} 2$ vs $\mathrm{G} 3$ \\
\hline SD & 0.03 & 0.03 & 0.03 & 0.05 & $p=0.001$ & $p=0.001$ & $p=0.065$ \\
\hline Nanocomposite & $\mathrm{Gl}$ & $\overline{\mathrm{G} 2}$ & G3 & Control G & $p=0.001$ & $p=0.001$ & $p=0.001$ \\
\hline Medie & 0.25 & 0.28 & 0.27 & 0.52 & $\mathrm{G} 1$ vs G2 & G1 vs G3 & $\mathrm{G} 2$ vs $\mathrm{G} 3$ \\
\hline SD & 0.03 & 0.02 & 0.04 & 0.05 & $p=0.006$ & $\mathrm{p}=0,262$ & $p=0,311$ \\
\hline Nanohybrid & $\overline{\mathrm{Gl}}$ & $\overline{\mathrm{G} 2}$ & G3 & Control G & $p=0.001$ & $p=0.001$ & $p=0.001$ \\
\hline Medie & 0.26 & 0.33 & 0.31 & 0.52 & $\mathrm{G} 1$ vs G2 & $\mathrm{G} 1$ vs $\mathrm{G} 3$ & $\mathrm{G} 2$ vs G3 \\
\hline SD & 0.03 & 0.03 & 0.03 & 0.05 & $p=0.001$ & $p=0.001$ & $p=0.025$ \\
\hline
\end{tabular}

higher than the Nanohibrid group (0.27 vs. $0.31, p=0.001$ ) (table 4).

In our study, G1 had the lowest Ra values for all tested composite resins followed by $\mathrm{G} 2$. After being stored for 90 days in artificial saliva, the composite samples showed a statistically lower $\mathrm{Ra}$ than the first determination. This is consistent with the study by Bonato et al. [15] which demonstrated how roughness decreases directly in proportion to time.

The Ra values obtained in this study for G1, G2, G3 groups at a time interval of 90 days from sample insertion in AFNOR artificial saliva show that in the Ormocer group, the lowest average roughness was noted at $\mathrm{Gl}(0,26 \pm$ $0.03)$, and the highest at $G 2(0.30 \pm 0.03)$. In the Nanocomposite lot, the lowest average roughness value was noted at $\mathrm{G} 1(0.25 \pm 0.03)$, the highest at $\mathrm{G} 2$ $(0.28 \pm 0.02)$. In the Nanohibrid group, the lowest average roughness value was noted for G1 solution (0.26 \pm 0.03$)$, the highest of $G 2(0.33 \pm 0.03)$. For all composites studied, over the 90-day interval in group $\mathrm{G} 3$, lower statistical values were observed compared to group $\mathrm{G} 2$.

These results confirm the findings of other studies regarding the sourface roughness of composite resisn. Catelan \& col. investigated the hypothesis that applying a sealant to the surface of composite restorations can improve the surface quality. Similar results were obtained by Perez $\&$ col. [16] who have evaluated the changes in surface condition after different finishing/polishing procedures for restorations made from two nanofill composite resins. Surface roughness evaluation was performed using a three-dimensional scanning device using the $\mathrm{Ra}$ and $\mathrm{Rz}$ parameters.

Another factor that might influence the surface state is represented by material intern structure (the shape, size and quantity of fillers) [17]. In our study there were recorded differences in surface roughness between the three analysed composite resins. All the materials have inorganic art higher than $65 \%$ by volume and represented by nanosized non-agglomerated/non aggregated silica particles and modified particles of silica and zyrconia dispersed between micro sized clusters. The best results were obtained after polishing lacquer on finished and polished surfaces with the Sof-Lex system (3M Dental Products), followed by the application of polishing lacquer on surfaces with diamond-cutters. It is possible that, nano-sized particles in the resin extern layer were eliminated first in finishing procedure and clusters having higher sizes remained on the top of the surface. The fabrication of nanofilled composite resins is accomplished by associating small particles in a more favorable thermodynamic model that leads to the formation of aggregates and clusters [18]. This could explain the low roughness of the observed surface for Filtek Ultimate specimens after polishing with the Sof-Lex system. This conservation of nanoclusters is possible due to the strong chemical interaction between the nanocluster and the resin matrix.

Finished and coated surfaces of composite resins restoration were previous analyze by Biazuz \& col. [19] regarding water absorption, solubility and surface roughness. Positive results were obtained, water absorption and solubility did not increase the surface roughness, which, according to the authors of the study, demonstrates the possibilities of their use in the long-term maintenance of the surface quality of composite resin restorations. In case of surface damage caused by contact with abrasive tools for finishing, the nanoparticle surface appears to suffer the least amount of mineral loss [20]. This would explain the low surface roughness of the samples made of these materials [18]. The micromorphology of hybrid composite resins, nanohybrids, microhydride resins after finishing and polishing is significantly influenced by the size, hardness and volume of the inorganic filler [21, 22].

There are a number of limitations of this study focusing on the evaluation of the surface quality of composite resin restorations, as a number of parameters are not included in the study design (the pressure applied during the finishing and polishing operations, the orientation of the abrasive surfaces, the time interval used for each stage and each tool used during finishing and polishing, type of abrasive included in the finishing and polishing tool structure). 
Aknowledgement: This work was supported bya grant of the Romanian Ministery of Research and Innovation, CCCDI - UEFISCDI, project number PN-III-P1-1.2-PCCDI-2017-0239 / 60PCCDI 2018, within PNCDI III

\section{Conclusions}

This study demonstrated that using composite sealant on composite resins restoration increases the possibility of long-term maintenance of a low surface roughness. Regardless the finishing or coating system used, nanocomposite and nanoceramic have significantly higher qualities than nanohybrid. Nanocomposite material presented the best values of roughness both at initial and after 90 days for all three groups, which makes us conclude that nanotechnology has had a beneficial effect on integrating stable chemical particles into the matrix of composite materials, contributing to the low wear rate of the materials.

\section{References}

1. DIETSCHI, D., CAMPANILE, G., HOLZ, J ., MEYER, J .M., Dent. Mater., 10, no.6, 1994, p. 353

2. IOVAN, G., STOLERIU, S., NICA, I., SOLOMON, S., MUNTEANU, A., ANDRIAN, S., Mater. Plast., 53, no. 4, 2016, p. 755.

3. YAP, A.U.J ., WU, S. S., CHELVAN, S., TAN, E.S.F., Oper. Dent., 30, no. 1, p. 99.

4. PANCU, G., STOLERIU, S., TOFAN, N., NICA, I., GHIORGHE, C.A., IOVAN, G., MOLDOVANU, A., MACOVEI, G., ANDRIAN, S., Rev. Chim. (Bucharest), 69, no. 7, 2018, p. 1871.

5. STOLERIU, S., PANCU, G., NICA, I., ANDRIAN, S., TOPOLICEANU, C., IOVAN, G., Mater. Plast., 53, no. 4, 2016, p. 752.

6.J EFFERIES, S.R., Dent. Clin. North Am., 51, no. 2, 2007, p. 379.
7. GÖNÜLOL, N., YILMAZ, F., J. Dent., 40, Suppl 2, 2012, p. 64.

8. EARAR, K., ANTONIAC, VI., BACIU, S., BRAN, S., ONISOR, F., MILEA, C., MOHAN, A., GRIGOROIU, R., SACELEANU, A., MANOLE, M., Rev. Chim. (Bucharest), 68, no. 11, 2017, p. 2700.

9.ANDRIAN, S., IOVAN, G., PANCU, G., TOPOLICEANU, C., GEORGESCU, A., STOLERIU, S., Mat. Plast., 54, no. 4, 2017, p. 689.

10. MUNTEANU, B., ANDRIAN, S., URSU, L., STOLERIU, S., IOVAN, G., GHIORGHE, C.A., PANCU, G., NICA, I., I.J.M.D., 6, no. 3, 2016, p. 124. 11. ERGÜCÜ, Z., TURKUN, L.S., Oper. Dent., 32, no. 2, 2007, p. 185. 12. MCCONNELL, M.D., LIU, Y., NOWAK, A.P., PILCH, S., MASTERS, J.G., COMPOSTO, R.J ., J. Biomed. Mater. Res. Part A, 9999A, 2009, no. 4, p. NA-NA.

13.KAPLAN,B.A., GOLDSTEIN, G.R., VIJAYARAGHAVAN, T.V., NELSON, I.K., J. Prosthet. Dent., 76, 1996, no. 1, p. 34.

14. BOLLEN, C.M., Lambrechts, P., Quirynen, M., Dent. Mater., 13, 1997, no. 4, p. 258.

15. BONATO, F., SPOHR, A.M., MOTA, E.G., RODRIGUES-J UNIOR, S.A., BURNETT, L.H., Am. J. Dent., 29, 2006, no. 1, p. 39.

16. PEREZ, C.R., HIRATA, R.J., da SILVA, A.H., SAMPAIO, E.M., Oper Dent, 6, 2009, p. 674.

17. ANDRIAN, S., PANCU, G., TOPOLICEANU, C., TOFAN, N., STOLERIU, S., IOVAN, G., Rev. Chim. (Bucharest), 68, no. 8, 2017, p. 1874.

18. STOLERIU, S., IOVAN, G., PANCU, G., NICA, I., ANDRIAN, S., Rom. J. Oral Rehabilit., 5, no. 3, 2013, p. 78.

19. BIAZUS, J., ZARDO, P., RODRIGUES jr., A., J. Oral SCl., 14, no. 1, 2015, p. 1677.

20. MITRA, S.B., WU, D., HOLMES, B.N., J. Am. Dent. Assoc., 134, 2003, no. 10, p. 1382.

21. YADAV, R.D., RAISINGANI, D., JINDAL, D., MATHUR, R., Int. J. Clin. Pediatr. Dent., 9, 2016, no. 3, p. 201.

22. ANDRIAN, S., MUNTEANU, B., TARABOANTA, I., NEGRAIA, D., NICA, P.E, STOLERIU, S., NICA, I., E-Health and Bioengineering Conference, 2017, ISBN 978-1-5386-0358-1/17.

Manuscript received:21.06.2018 